Int. J. Electrochem. Sci., 11 (2016) $5900-5908$

\title{
Electrocatalytic Activity of Co-based Perovskite Oxides for Oxygen Reduction and Evolution Reactions
}

\author{
Boyoon Shin, Sangwon Choi, Yongsug Tak \\ Department of Chemical Engineering, Inha University, 253 Yonghyun-dong, Nam-ku, Incheon 402- \\ 751, Republic of Korea \\ *E-mail: ystak@inha.ac.kr
}

doi: $10.20964 / 2016.07 .68$

Received: 24 February 2016 / Accepted: 14 April 2016 / Published: 4 June 2016

\begin{abstract}
Cathode of aqueous $\mathrm{Li}$-air batter requires high electrocatalytic activities for oxygen reduction reaction and oxygen evolution reaction. Pure Co-based perovskite oxide $\left(\mathrm{LaCoO}_{3}\right)$ was prepared by an autocombustion method at a relatively low calcination temperature $\left(640^{\circ} \mathrm{C}\right)$, and $\mathrm{La}$ of $\mathrm{La}_{1-\mathrm{x}} \mathrm{Sr}_{\mathrm{x}} \mathrm{CoO}_{3}$ was partially substituted with $\mathrm{Sr}$ to enhance its electrocatalytic activities. $\mathrm{La}_{0.7} \mathrm{Sr}_{0.3} \mathrm{CoO}_{3}$ showed excellent catalytic activity for the oxygen evolution reaction, and its activity for the oxygen reduction reaction was increased with $5 \mathrm{wt} \% \mathrm{Pt}$ loading. The electrochemical activity of perovskite was investigated by linear sweep voltammetry and electrochemical impedance spectroscopy.
\end{abstract}

Keywords: perovskite oxides, oxygen reduction reaction, oxygen evolution reaction, $\mathrm{LaCoO}_{3}$, electrochemical analysis

\section{$\underline{\text { FULL TEXT }}$}

(C) 2016 The Authors. Published by ESG (www.electrochemsci.org). This article is an open access article distributed under the terms and conditions of the Creative Commons Attribution license (http://creativecommons.org/licenses/by/4.0/). 